Article

\title{
Exploring the Preferences of Iranian Geotourists: Case Study of Shadows Canyon and Canyon of Jinns
}

\author{
Nemanja Tomić ${ }^{1, *}$, Babak Sepehriannasab ${ }^{2}$, Slobodan B. Marković ${ }^{1}$, Qingzhen Hao ${ }^{3}$ \\ and Heros Augusto Santos Lobo ${ }^{4}$ \\ 1 Department of Geography, Tourism and Hotel Management, Faculty of Sciences, University of Novi Sad, \\ Trg Dositeja Obradovića 3, 21000 Novi Sad, Serbia; slobodan.markovic@dgt.uns.ac.rs \\ 2 Department of Science, Izeh Branch, Islamic Azad University, Izeh 63, Iran; babakbabalou@gmail.com \\ 3 Key Laboratory of Cenozoic Geology and Environment, Institute of Geology and Geophysics, \\ Chinese Academy of Sciences, Beijing 100029, China; haoqz@mail.iggcas.ac.cn \\ 4 Department of Geography, Tourism and Humanities, Federal University of São Carlos, \\ Sorocaba 13565-905, Brazil; heroslobo@ufscar.br \\ * Correspondence: airtomic@gmail.com
}

check for updates

Citation: Tomić, N.; Sepehriannasab, B.; Marković, S.B.; Hao, Q.; Lobo, H.A.S. Exploring the Preferences of Iranian Geotourists: Case Study of Shadows Canyon and Canyon of Jinns. Sustainability 2021, 13, 798. https://doi.org/10.3390/su13020798

Received: 10 December 2020 Accepted: 12 January 2021 Published: 15 January 2021

Publisher's Note: MDPI stays neutral with regard to jurisdictional clai$\mathrm{ms}$ in published maps and institutional affiliations.

Copyright: (C) 2021 by the authors. Licensee MDPI, Basel, Switzerland. This article is an open access article distributed under the terms and conditions of the Creative Commons Attribution (CC BY) license (https:// creativecommons.org/licenses/by/ $4.0 /)$.

\begin{abstract}
Compared to other parts of the country, the region of Central Iran still remains mainly outside of major tourism flows even though there are significant geosites with great value for geotourism development. Two of those sites, the Shadow Canyon and the Canyon of Jinns, have excellent qualities for the development of this form of tourism in the future. The goal of this research is to gain information about the preferences of Iranian geotourists and to determine the current state and geotourism potential of Shadows Canyon and Jinn Canyon located in Central Iran by applying the modified geosite assessment model (M-GAM). The results indicate that Iranian geotourists consider rarity and the number of viewpoints the most important when choosing which geosite to visit, while the least important are tour guide service as well as hostelry and restaurant service. The results also show that more attention should primarily be concentrated toward promotional activities and basic tourist infrastructure construction in the future to attract even more tourists to these and other geosites in Iran.
\end{abstract}

Keywords: geoheritage; geodiversity; modified geosite assessment model (M-GAM); geotourism; Iran; canyons

\section{Introduction}

Canyons have been popular tourism destinations since the late 18th century. Nowadays, these types of natural features are among the most popular geotourism attractions on Earth. Sites such as the Grand Canyon (USA), Antelope Canyon (USA), Samaria Gorge (Greece), Three Gorges (China), Vintgar Gorge (Slovenia), and many others receive a large number of tourists every year [1,2]. Tourism interest in these and similar geological formations and landscapes has been rapidly increasing in the last decade. Consequently, geoheritage and geosites now have a much bigger role and greater importance in the overall tourism offer in most countries [3-6]. Evidence of this can be found especially in less developed countries where mass tourism is still not present [1]. Many of these countries, including Iran, are beginning to realize the importance and potential contribution of tourism revenue to their economic development. Due to the international economic sanctions on Iran and its oil and gas industry, the Iranian government is making efforts to attract more tourists and therefore enhance economic development [7].

When it comes to tourism, Iran is mainly known for its ancient and rich cultural heritage and history rather than its natural resources, except oil and gas resources. This is no surprise, given the fact that the country has a large number of historical and archaeological sites representing human history dating back 10,000 years in the past [8]. The diverse 
history and culture of this country originates from the fact that it has always been at the intersection of international trade routes between the Middle East, Asia, and Europe [8].

However, besides this rich cultural heritage, Iran possesses many natural tourist resources that are attracting more and more visitors every year. The mountain ranges, plateaus, plains, and deserts of Iran are home to many rivers, lakes, canyons, caves, and other sites that are the foundation for nature-based forms of tourism, including geotourism. This type of tourism represents a form of sustainable tourism based on geodiversity and geoheritage [9], providing nature protection by minimizing the negative effects of tourism through geoconservation [10]. Apart from these elements, it also provides economic support and job creation for local communities in rural areas by introducing local history and culture to tourists.

This combination of both natural and cultural resources makes Iran a complex tourism destination interesting for many different profiles of tourists who can enjoy both winter activities as well as summer activities within the same months of the year. On the other hand, some of Iran's large deserts have a reputation among people as dangerous places with no tourist attractions. However, this has been changing in recent years as some of these areas are being promoted as geotourism destinations and are becoming more popular among younger generations [11]. Due to this fact, more and more geosites are being identified and established as geotourism destinations (Alisadr Cave, Katalekhor Cave, Gol-Feshan Spring of Chabahar, Tange Washi), especially those at Qeshm Island (Stars Valley, Chah-kooh Gorge, Shor Valley, Tang-e Awli Gorge,) in the southern part of the country [11,12]. Iran's geotourism is currently mainly based on the first and only geopark located at the southwestern part of Qeshm Island. Geotourism development was first initiated in 2001 by Alireza Amrikazemi from the Geological Survey of Iran. Alireza wrote the first publication about geotourism in Iran entitled "Introducing geotourism in Iran" [13], followed in 2004 by the Atlas of the Qeshm geotourism, a look at the geological features of the Qeshm Island [14], which focused on Qeshm Island, which still remains the main geotourism destination of the country with the Valley of the Stars as one of its biggest attractions. Other popular geotourism attractions include the Katalekhor and Alisadr Caves located around $300 \mathrm{~km}$ west from Tehran, as well as several canyons and gorges located throughout the country (Raghaz Canyon, Tang-e Boraq and Hayghar Valley in the Fars province; Shiraz Canyon in Lorestan province). Along with Qeshm Island, these are the most visited geotourism destinations of Iran.

Current tourist visits to canyons in Iran are mostly limited to well-known sites such as Stars Valley at the Qeshm Geopark in the southern part of the country and Tange Washi located in the Tehran province close to the capital of Iran. However, geotourism activities at these sites are very scarce even though some of them possess irrefutable aesthetic as well as scientific qualities. Two such sites, the Shadows Canyon and Canyon of Jinns (Kal-e Jenni), are located in Central Iran.

The goal of this paper is to examine the preferences of Iranian geotourists by calculating the Importance ( $\mathrm{Im}$ ) factor of each subindicator in the M-GAM (Modified Geosite Assessment Model) model. Additionally, the paper also aims to apply the resulting Im values to establish the current state and geotourism potential of Shadows Canyon and the Canyon of Jinns located in Central Iran. These two sites were analyzed by using the M-GAM model [15] for geosite assessment. Before the assessment was carried out, research was carried out through a survey among Iranian geotourists to determine the importance of each subindicator in the M-GAM model and to give us a clear picture of the preferences and needs of Iranian geotourists who visit such geosites. The use of this methodology revealed which subindicators most influence geotourists' opinions when deciding which geosite they will visit. These results were later compared to those from Slovenia and Serbia, since these are the only two countries that have calculated the Importance factor for their geotourists so far $[1,16]$. The assessment results have also provided us data related to key areas requiring improvement in the future so that the geotourism offer could be enhanced not only at the analyzed sites but at other geosites in Iran as well. 


\section{Study Area}

Iran is a country in the Middle West and Southwest part of the Asian continent. Approximately little over half of its surface is mountainous while the rest consists of plateaus, deserts, lakes, saline lands, and plains. The southern part of the country has access to the Persian Gulf and Oman Sea. The mountainous part of the country is characterized by the Alborz and Zeroes mountain ranges to the north and west, while the majority of Iranian deserts are located in between [17]. Both analyzed canyons are located on a plateau in Central Iran (Figures 1 and 2) on the edges of the Dasht-e Kavir Desert (the Great Salt Desert). This part of the country represents one of the most complicated structural zones in Iran. Rocks from the Precambrian to the Quaternary can be found here. Additionally, evidence of orogeny, magmatism, and metamorphism can also be identified [18]. It is a tectonically active region and it contains several continental sections that have been joined together along a suture zone of oceanic character. A major influence on the geological evolution of Iran was the continental convergence, preceded by the floor subduction of the Neo-Tethys Ocean beneath Iran, which in turn led to the joining of Iran and Arabia. Based on structural trends, the Iranian plateau can be divided into six parts: Zagros Orogenic Belt, Metamorphic zone of Sanandaj-Sirjan, Urmia-Dokhtar magmatic arc (UDMA), Central Iran, Alborz, and Eastern Iran [17].

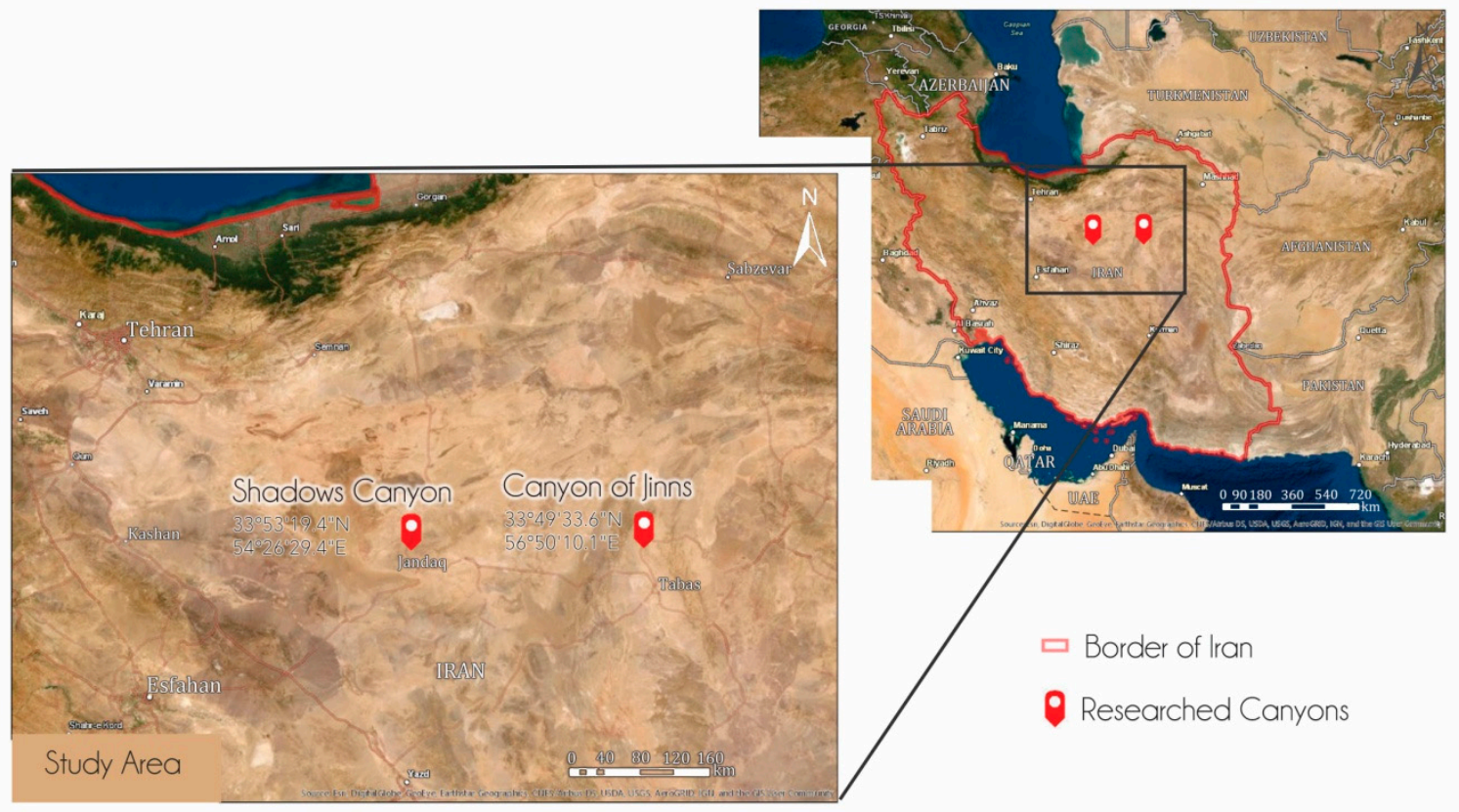

Figure 1. Position of analyzed canyons in Iran. Source of Basemap: Esri, DigitalGlobe, GeoEye, Earthstar Geographics, CNES/Airbus DS, USDA, USGS, AeroGRID, IGN and the GIS User Community.

A large part of Central Iran is the Dasht-e Kavir Desert (approximately $390 \mathrm{~km}$ wide, covering a surface of $77,600 \mathrm{~km}^{2}$ ), located southeast from the Alborz Mountains and north from the Lut Desert. With an average elevation of $900-1000 \mathrm{~m}$ it is one of the driest places in the world with a very arid climate and temperatures easily reaching $50^{\circ} \mathrm{C}$ in the summer. These high temperatures cause intense water evaporation, leaving behind sandy, clay soils and marshes covered with salty crusts. Nevertheless, the surrounding mountains are a source of runoff water, which has in turn led to the creation of seasonal lakes and marshlands. Aeolian deposits are dominant here in the form of sand dunes that can reach up to $40 \mathrm{~m}$ in height due to frequent heavy storms [19-21]. 

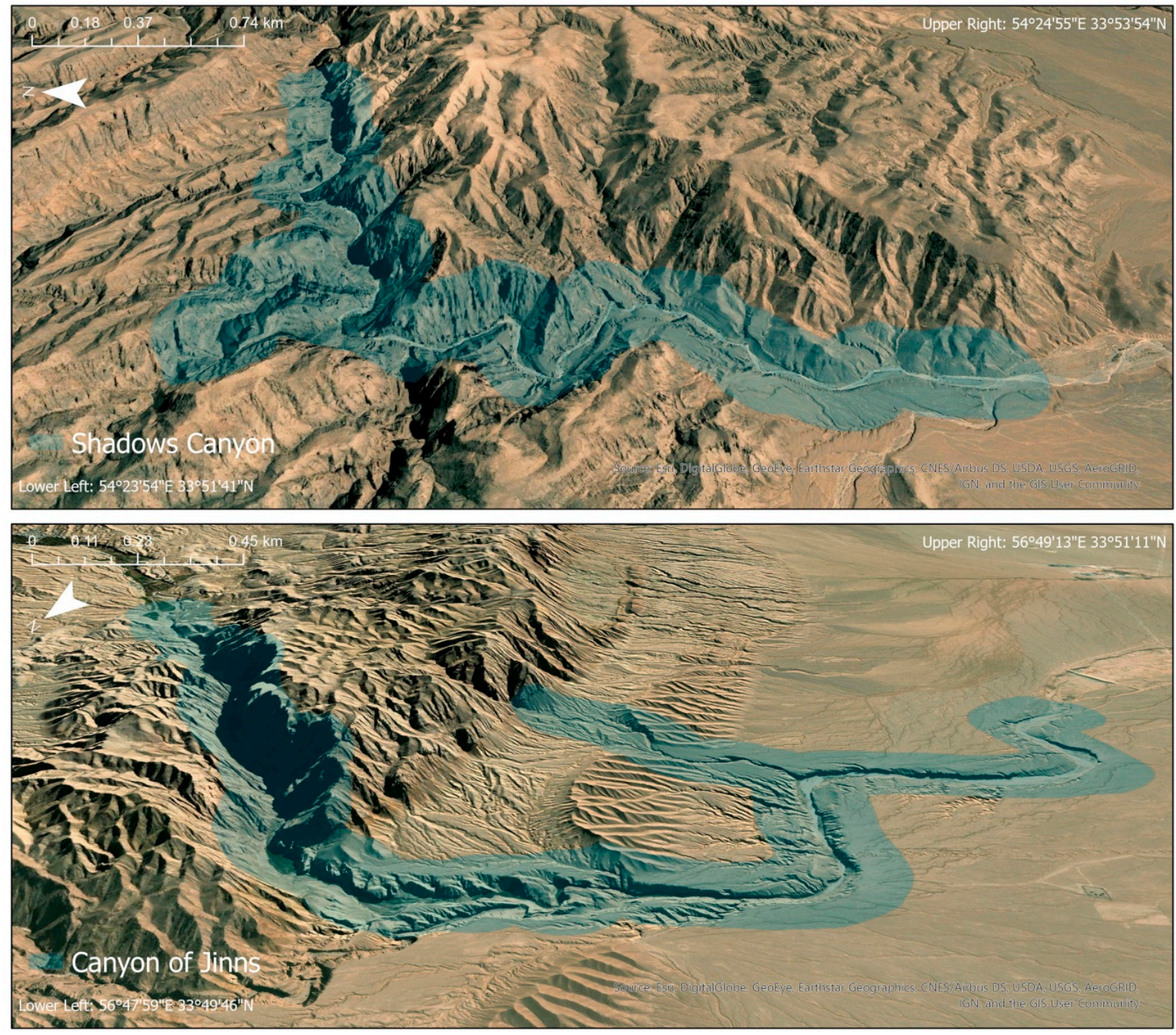

Figure 2. 3D aerial image of the study area. Source of Basemap: Esri, DigitalGlobe, GeoEye, Earthstar Geographics, CNES/Airbus DS, USDA, USGS, AeroGRID, IGN and the GIS User Community.

Shadows Canyon (Darreye Oham) is located at 1150 to $1350 \mathrm{~m}$ above sea level in the Esfahan province, surrounded by sandy, high mountains (Figures 2-4). It is about $7 \mathrm{~km}$ long and it is composed of sedimentary rocks, mainly Jurassic limestone (part of the Esfandiar reef Limestone Formation) and Paleogene igneous rocks such as dacite, andesite, and tuff. For most of its length, its sides are from 100 to $180 \mathrm{~m}$ in height. It belongs to the northern part of the Lut Block, which was hardened during the Cimmerian and Alpine orogeny.

The closest town to the canyon is the town of Jandaq, with a population of nearly 5000 hospitable and hardworking desert people. This ancient town lies on the edge of the Dasht-e Kavir Desert (The Great Salt Desert) near the famous historical Silk Road, and its name means "desert harbor", coming from the fact that this town was a rest area for caravans traveling along the Silk Road. It is also worth mentioning that Jandaq is $70 \mathrm{~km}$ south from the southern border of Semnan province and $260 \mathrm{~km}$ from Damghan city, on the road that connects Isfahan and Mashhad, as well as Tehran and Birjand. 


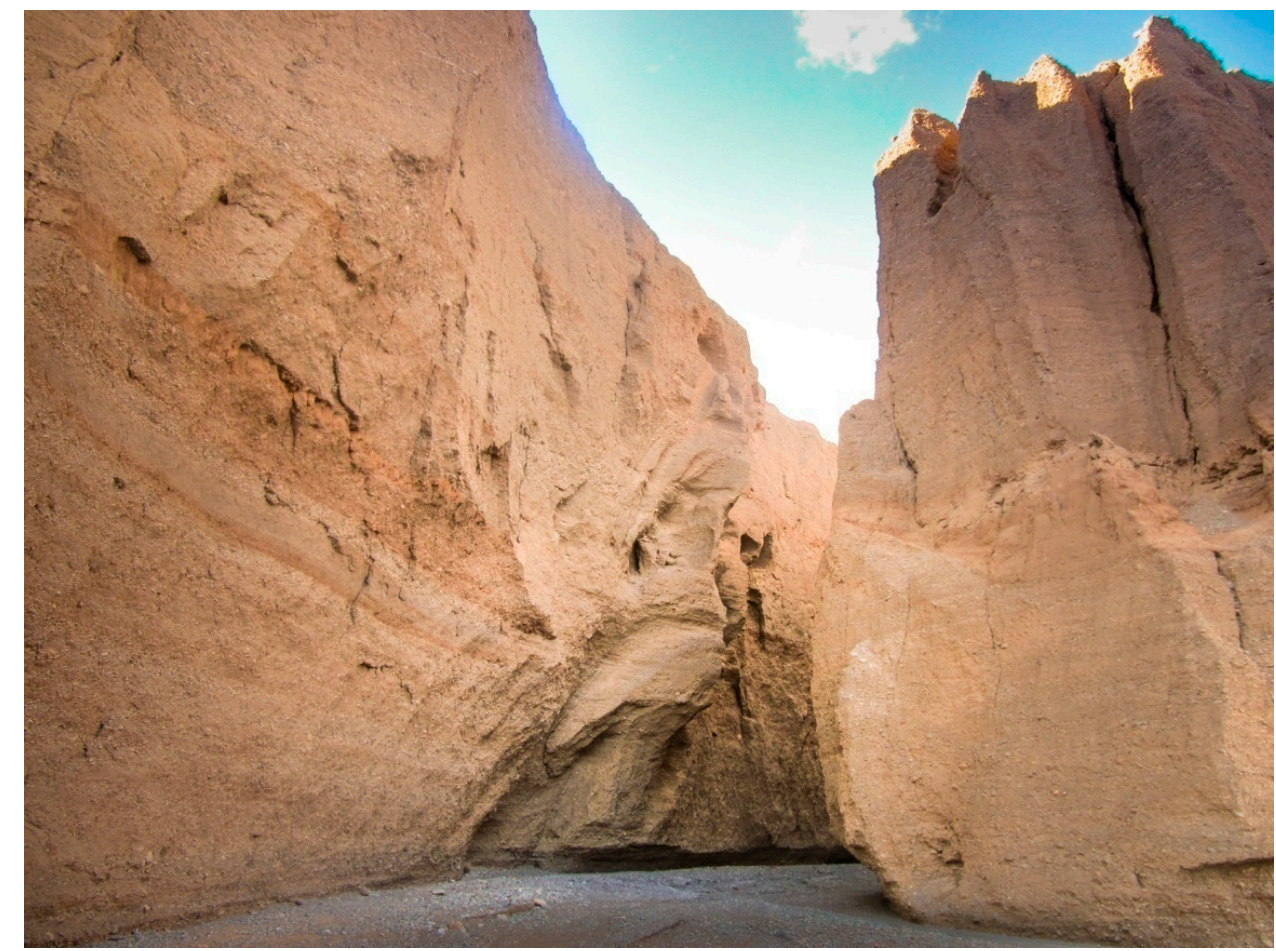

Figure 3. Entrance of Shadows Canyon. Source: Babak Sepehriannasab.

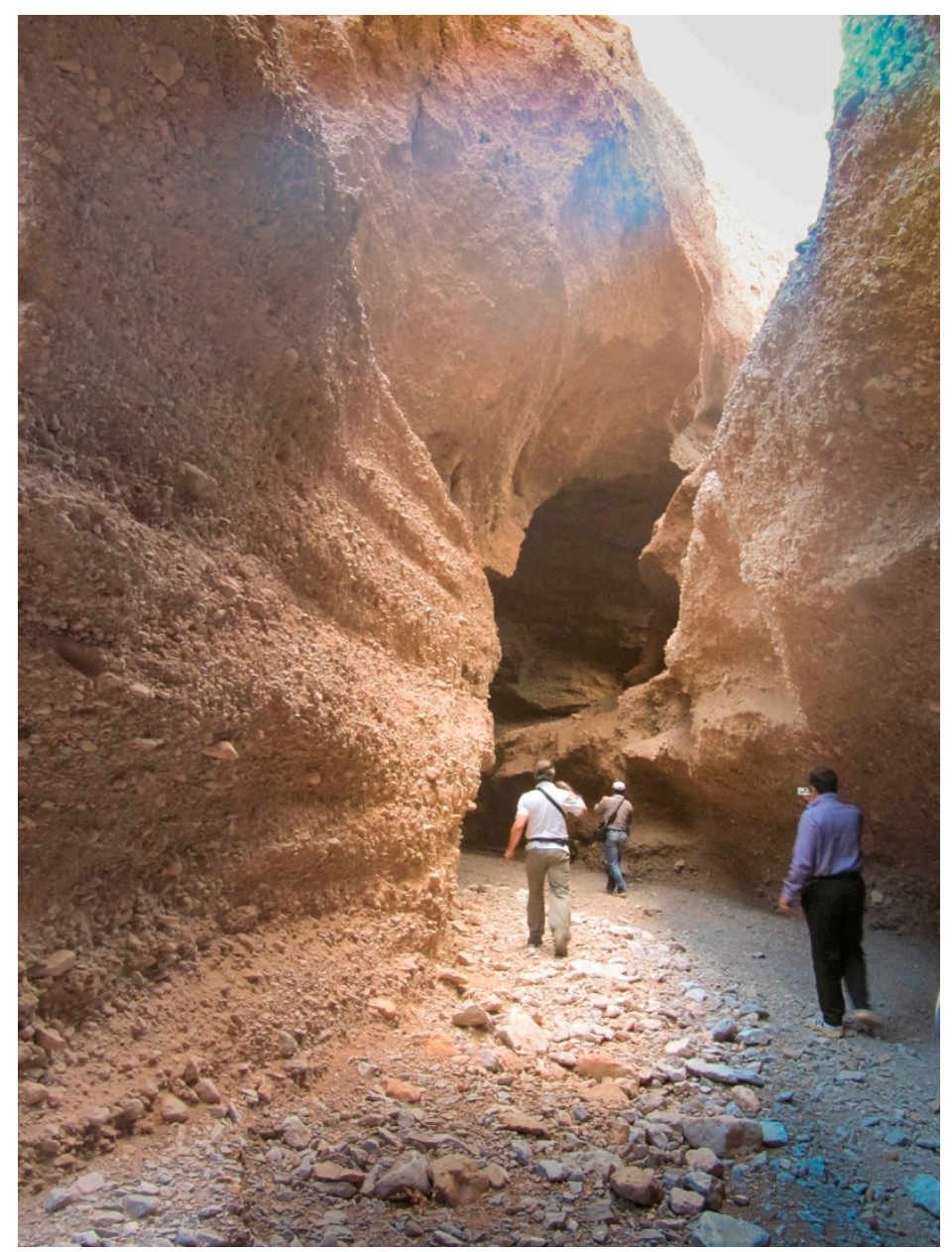

Figure 4. Walking through Shadows Canyon. Source: Babak Sepehriannasab. 
Even though Jandaq is nearby, the canyon still remains mainly unexplored and unknown, not only for the world, but also for the majority of Iranian people as well. Apart from the experience of several local shepherds who entered the canyon occasionally, there have been no previous descriptions of the valley's characteristics and features. The canyon was created by the Changak River, whose riverbed is currently dry. This old river has created one of the most beautiful canyons on the central plateau of Iran. Tourists from Tehran, Isfahan, and Yazd can travel to the region through the Jandaq Road and reach the canyon. The sandy hills northeast of the Shadows Canyon are a suitable place for sand boarding, off-roading, zip lining, or camel riding. Another settlement, the Mesr historical and tourist village, is located nearby and tourists can visit the canyon alongside visiting the village. The vicinity of Jandaq and Mesr village, along with their facilities and tourism infrastructure, can provide support for tourism activities and serve as a base and a starting point for future tourist visits to this area.

The Canyon of Jinns (Kal-e Jenni) is located in the South-Khorasan Province, $35 \mathrm{~km}$ north of the city of Tabas, around the village of Ezmeyghan, which is a typical desert village. It is about $16 \mathrm{~km}$ long at 750 to $1000 \mathrm{~m}$ above sea level, with its sides rising to $200 \mathrm{~m}$. The oldest parts of this canyon belong to fossiliferous limestones of the Esfandiar formation (Upper Jurassic) that formed the mountainous part of this canyon. Parts of this canyon also include Neogene sediments and a considerable amount of alluvial sediments where several interesting geological and geomorphological features were formed due to loose alluvial sediments and Neogene conglomerates [22].

Its name originates from the belief that jinns and ghosts inhabit the canyon grounds. Stories of this can be traced back to the native population that lived in this area during the past. The canyon sides and the surrounding area are very distinctive, with high and steep slopes created by the forces of wind and torrential rains over millions of years (Figure 5). In some parts, the canyon is U-shaped and in other parts it is V-shaped.

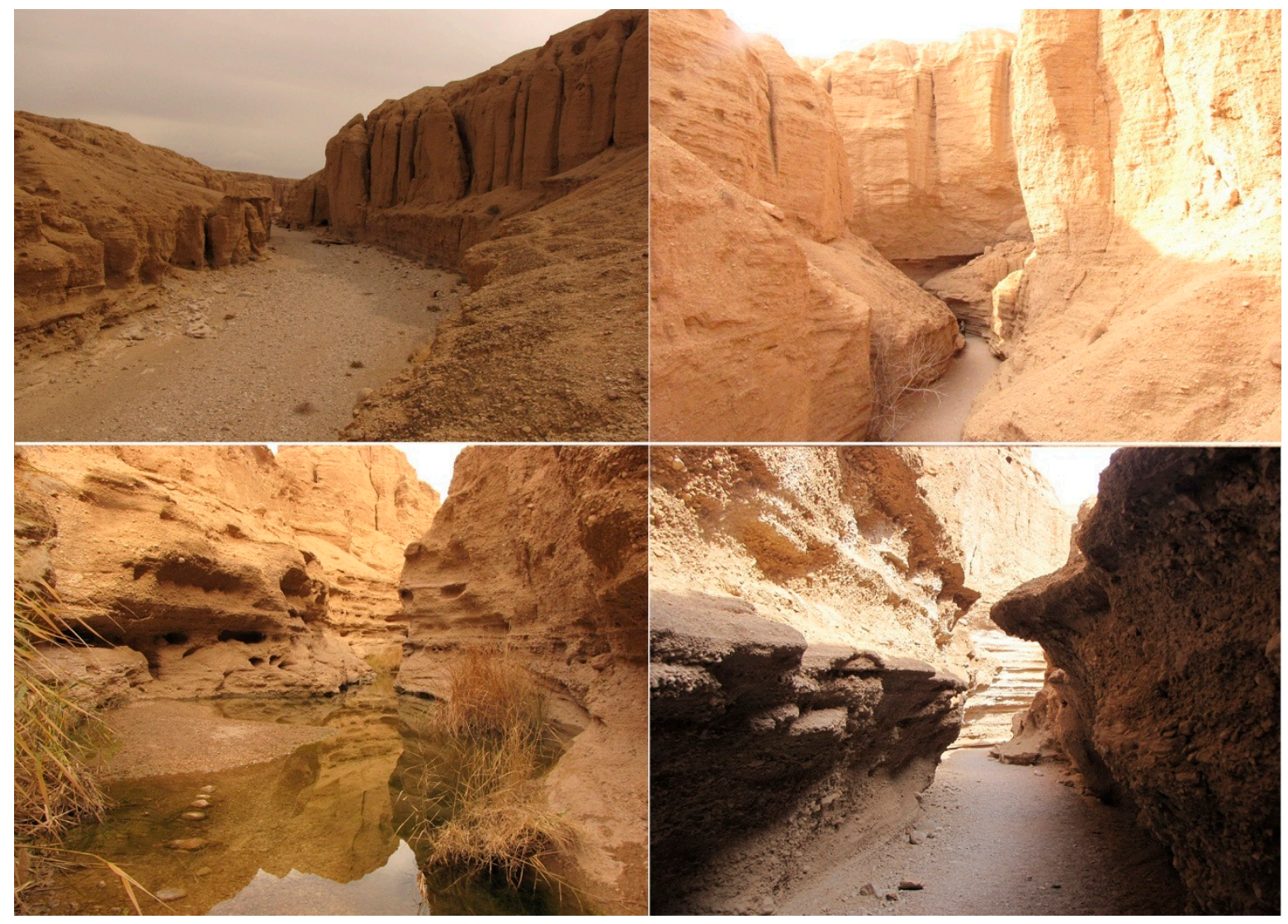

Figure 5. The Canyon of Jinns. Source: Babak Sepehriannasab. 
There are several tunnels and holes that were carved out in the canyon walls in the past by Zoroastrians for living. These man-made chambers date back to the Sassanid era, and it is speculated by some that their original purpose was for meditation, while others consider that the locals used them for storing goods and hiding from danger. Apart from these chambers there are also several smaller ponds and periodic waterfalls. Given the scarcity of water in the surrounding area, at some places the groundwater has been diverted through canals by the local people and used for irrigation.

\section{Methodology}

Since the beginning of the 21st century, geotourism has been constantly gaining popularity throughout the world [23-26]. This form of tourism is mainly related to geosites (geological heritage) and geomorphosites (geomorphological heritage). Their identification and assessment are considered as essential steps in the development of geotourism and protection of geoheritage [27]. Geosite assessment and the determination of geosite value to potential geotourists and researchers is largely identified as key instruments for successful geosite management and geotourism development and also for geoconservation activities on a certain territory. As a response to this, several authors have shifted their focus to geosite and geomorphosite assessment [15,16,28-39] so that the present state and geotourism potential of geosites could be identified and more attention given toward their protection. Consequently, various evaluation and assessment models developed in previous years are now an important instrument for the enhancement of geotourism products and also serve as guidelines for geosite management.

The methodology used in this research is based upon the modified geosite assessment model (M-GAM) developed by Tomić and Božić [15]. This method originates from past geosite assessment methods developed by different authors [28,30,40-47] and the Importance factor ( $\mathrm{Im}$ ) first introduced by Tomić [29]. Its advantage is that it integrates the opinions of both tourists and experts so that none of them is favored throughout the assessment process. The model has been successfully applied plenty of times for the assessment of several geosites in Serbia [1,15,48-60], Slovenia [16], USA [52,61] and in the Hungarian Bakony-Balaton geopark [39].

The M-GAM evaluation method has two primary indicators: Main Values and Additional Values, which consist of 27 subindicators in total that are further divided into two groups (12 and 15), each one of them individually scored from 0 to 1 . This division is done mainly because of two general types of values: Main Values-mostly generated by the geosite's natural characteristics-and Additional Values, which are mostly humaninduced. The Main Values consist of three subindicator groups: scientific/educational (VSE), scenic/aesthetical values (VSA) and protection (VPr), while the Additional Values are divided into two groups of indicators, functional (VFn) and touristic values (VTr). The Main and Additional Values are presented in more detail in Table 1. In total, there are 12 subindicators of Main Values, and 15 subindicators of Additional Values, which are scored from 0 to 1 , that define M-GAM as a simple equation:

$$
\mathrm{M}-\mathrm{GAM}=M V+A V
$$

where $M V$ and $A V$ represent symbols for Main and Additional Values. Since Main and Additional Values consist of three or two groups of subindicators, we can derive these two equations:

$$
\begin{gathered}
M V=\mathrm{VSE}+\mathrm{VSA}+\mathrm{VPr}, \\
A V=\mathrm{VFn}+\mathrm{VTr} .
\end{gathered}
$$


Table 1. The structure of the modified geosite assessment model (M-GAM).

\begin{tabular}{|c|c|}
\hline Indicators/Subindicators & Description \\
\hline \multicolumn{2}{|l|}{ Main Values $(M V)$} \\
\hline \multicolumn{2}{|l|}{$\begin{array}{l}\text { Scientific/Educational Value } \\
\text { (VSE) }\end{array}$} \\
\hline 1. Rarity & Number of closest identical sites \\
\hline 2. Representativeness & Didactic and exemplary characteristics of the site due to its own quality and general configuration \\
\hline $\begin{array}{l}\text { 3. Knowledge of } \\
\text { geoscientific issues }\end{array}$ & Number of written papers in acknowledged journals, theses, presentations, and other publications \\
\hline 4. Level of interpretation & $\begin{array}{l}\text { Level of interpretive possibilities for geological and geomorphologic processes, phenomena, and shapes and level } \\
\text { of scientific knowledge }\end{array}$ \\
\hline \multicolumn{2}{|l|}{ Scenic/Aesthetic (VSA) } \\
\hline 5. Viewpoints & $\begin{array}{l}\text { Number of viewpoints accessible by a pedestrian pathway. Each must present a particular angle of view and be } \\
\text { situated less than } 1 \mathrm{~km} \text { from the site }\end{array}$ \\
\hline 6. Surface & Whole surface of the site. Each site is considered in quantitative relation to other sites \\
\hline $\begin{array}{l}\text { 7. Surrounding landscape } \\
\text { and nature }\end{array}$ & $\begin{array}{l}\text { Panoramic view quality, presence of water and vegetation, absence of human-induced deterioration, vicinity of } \\
\text { urban area, etc. }\end{array}$ \\
\hline $\begin{array}{l}\text { 8. Environmental fitting } \\
\text { of sites }\end{array}$ & Level of contrast to the nature, contrast of colors, appearance of shapes, etc. \\
\hline \multicolumn{2}{|l|}{ Protection $(\mathrm{VPr})$} \\
\hline 9. Current condition & Current state of geosite \\
\hline 10. Protection level & Protection by local or regional groups, national government, international organizations, etc. \\
\hline 11. Vulnerability & Vulnerability level of geosite \\
\hline $\begin{array}{l}\text { 12. Suitable number } \\
\text { of visitors }\end{array}$ & $\begin{array}{l}\text { Proposed number of visitors on the site at the same time, according to surface area, vulnerability, and current state } \\
\text { of geosite }\end{array}$ \\
\hline \multicolumn{2}{|l|}{ Additional Values $(A V)$} \\
\hline \multicolumn{2}{|l|}{ Functional values (VFn) } \\
\hline 13. Accessibility & Possibilities of approaching to the site \\
\hline 14. Additional natural values & Number of additional natural values in the radius of $5 \mathrm{~km}$ (geosites also included) \\
\hline $\begin{array}{l}\text { 15. Additional anthropogenic } \\
\text { values }\end{array}$ & Number of additional anthropogenic values in the radius of $5 \mathrm{~km}$ \\
\hline $\begin{array}{l}\text { 16. Vicinity of } \\
\text { emissive centers }\end{array}$ & Closeness of emissive centers \\
\hline $\begin{array}{l}\text { 17. Vicinity of important } \\
\text { road network }\end{array}$ & Closeness of important road networks in the radius of $20 \mathrm{~km}$ \\
\hline $\begin{array}{l}\text { 18. Additional functional } \\
\text { values }\end{array}$ & Parking lots, gas stations, mechanics, etc. \\
\hline \multicolumn{2}{|l|}{ Touristic values (VTr) } \\
\hline 19. Promotion & Level and number of promotional resources \\
\hline 20. Organized visits & Annual number of organized visits to the geosite \\
\hline 21. Vicinity of visitors centers & Closeness of visitor center to the geosite \\
\hline 22. Interpretative panels & Interpretative characteristics of text and graphics, material quality, size, fitting to surroundings, etc. \\
\hline 23. Number of visitors & Annual number of visitors \\
\hline 24. Tourism infrastructure & Level of additional infrastructure for tourist (pedestrian pathways, resting places, garbage cans, toilets, etc.) \\
\hline 25. Tour guide service & If it exists, expertise level, knowledge of foreign language(s), interpretative skills, etc. \\
\hline 26. Hostelry service & Hostelry service close to geosite \\
\hline 27. Restaurant service & Restaurant service close to geosite \\
\hline
\end{tabular}


Table 1. Cont.

\begin{tabular}{|c|c|c|c|c|c|}
\hline \multirow{2}{*}{$\begin{array}{c}\text { Indicators/Subindicators } \\
\text { Main Values }(M V)\end{array}$} & \multicolumn{5}{|c|}{ Description } \\
\hline & & & & & \\
\hline & \multicolumn{5}{|l|}{ Scores (0.00-1.00) } \\
\hline & 0.00 & 0.25 & 0.50 & 0.75 & 1.00 \\
\hline 1. & Common & Regional & National & International & The only occurence \\
\hline 2. & None & Low & Moderate & High & Utmost \\
\hline 3. & None & Local publications & Regional publications & National publications & $\begin{array}{l}\text { International } \\
\text { publications }\end{array}$ \\
\hline 4. & None & $\begin{array}{l}\text { Moderate level of } \\
\text { processes but hard } \\
\text { to explain } \\
\text { to non-experts }\end{array}$ & $\begin{array}{l}\text { Good example of } \\
\text { processes but hard } \\
\text { to explain } \\
\text { to non-experts }\end{array}$ & $\begin{array}{l}\text { Moderate level of } \\
\text { processes but easy to } \\
\text { explain to } \\
\text { common visitor }\end{array}$ & $\begin{array}{l}\text { Good example of } \\
\text { processes and easy } \\
\text { to explain to } \\
\text { common visitor }\end{array}$ \\
\hline 5. & None & 1 & 2 to 3 & 4 to 6 & More than 6 \\
\hline 6. & Small & - & Medium & - & Large \\
\hline 7. & - & Low & Medium & High & Utmost \\
\hline 8. & Unfitting & - & Neutral & - & Fitting \\
\hline 9. & $\begin{array}{l}\text { Totally damaged } \\
\text { (as a result of } \\
\text { human activities) }\end{array}$ & $\begin{array}{l}\text { Highly damaged (as } \\
\text { a result of } \\
\text { natural processes) }\end{array}$ & $\begin{array}{l}\text { Medium damaged } \\
\text { (with essential } \\
\text { geomorphologic } \\
\text { features preserved) }\end{array}$ & Slightly damaged & No damage \\
\hline 10. & None & Local & Regional & National & International \\
\hline 11. & $\begin{array}{l}\text { Irreversible (with } \\
\text { possibility of } \\
\text { total loss) }\end{array}$ & $\begin{array}{l}\text { High (could be } \\
\text { easily damaged) }\end{array}$ & $\begin{array}{l}\text { Medium (could be } \\
\text { damaged by natural } \\
\text { processes or } \\
\text { human activities) }\end{array}$ & $\begin{array}{l}\text { Low (could be } \\
\text { damaged only by } \\
\text { human activities) }\end{array}$ & None \\
\hline 12. & 0 & 0 to 10 & 10 to 20 & 20 to 50 & More than 50 \\
\hline 13. & Inaccessible & $\begin{array}{l}\text { Low (on foot with } \\
\text { special equipment } \\
\text { and expert } \\
\text { guide tours) }\end{array}$ & $\begin{array}{l}\text { Medium (by bicycle } \\
\text { and other means of } \\
\text { man-powered } \\
\text { transport) }\end{array}$ & High (by car) & Utmost (by bus) \\
\hline 14. & None & 1 & 2 to 3 & 4 to 6 & More than 6 \\
\hline 15. & None & 1 & 2 to 3 & 4 to 6 & More than 6 \\
\hline 16. & More than $100 \mathrm{~km}$ & 100 to $50 \mathrm{~km}$ & 50 to $25 \mathrm{~km}$ & 25 to $5 \mathrm{~km}$ & Less than $5 \mathrm{~km}$ \\
\hline 17. & None & Local & Regional & National & International \\
\hline 18. & None & Low & Medium & High & Utmost \\
\hline 19. & None & Local & Regional & National & International \\
\hline 20. & None & Less than 12 per year & 12 to 24 per year & 24 to 48 per year & $\begin{array}{l}\text { More than } 48 \text { per } \\
\text { year }\end{array}$ \\
\hline 21. & More than $50 \mathrm{~km}$ & 50 to $20 \mathrm{~km}$ & 20 to $5 \mathrm{~km}$ & 5 to $1 \mathrm{~km}$ & Less than $1 \mathrm{~km}$ \\
\hline 22. & None & Low quality & Medium quality & High quality & Utmost quality \\
\hline 23. & None & Low (less than 5000) & $\begin{array}{l}\text { Medium (5001 } \\
\text { to } 10,000)\end{array}$ & $\begin{array}{l}\text { High }(10,001 \\
\text { to } 100,000)\end{array}$ & $\begin{array}{l}\text { Utmost (more } \\
\text { than } 100,000 \text { ) }\end{array}$ \\
\hline 24. & None & Low & Medium & High & Utmost \\
\hline 25. & None & Low & Medium & High & Utmost \\
\hline 26. & More than $50 \mathrm{~km}$ & $25-50 \mathrm{~km}$ & $10-25 \mathrm{~km}$ & $5-10 \mathrm{~km}$ & Less than $5 \mathrm{~km}$ \\
\hline 27. & More than $25 \mathrm{~km}$ & $10-25 \mathrm{~km}$ & $10-5 \mathrm{~km}$ & $1-5 \mathrm{~km}$ & Less than $1 \mathrm{~km}$ \\
\hline
\end{tabular}

Now that we know that each group of indicators consists of several subindicators, Equations (2) and (3) can be written as follows:

$$
M V=\mathrm{VSE}+\mathrm{VSA}+\mathrm{VPr} \equiv \sum_{i=1}^{12} \operatorname{SIM} V_{i}, \text { where } \quad 0 \leq S \operatorname{SIM} V_{i} \leq 1,
$$




$$
A V=\mathrm{VFn}+\mathrm{VTr} \equiv \sum_{j=1}^{15} S I A V_{i}, \text { where } \quad 0 \leq S I A V_{j} \leq 1 .
$$

Here, $\operatorname{SIMV}_{i}$ and $\operatorname{SIAV} V_{j}$ represent 12 subindicators of Main Values $(i=1, \ldots, 12)$ and 15 subindicators $(j=1, \ldots, 15)$ of Additional Values. The key feature of M-GAM is that it does not focus only on the expert's opinion but also on geotourists' opinions regarding the importance of each indicator in the assessment process. The inclusion of tourists in the assessment process is done through a survey where each respondent is asked to rate the Importance ( $I m$ ) of all 27 subindicators (from 0.00 to 1.00) in the M-GAM model. The Importance factor ( $\mathrm{Im}$ ) gives tourists the possibility to express their opinion about each subindicator in the model and about how important it is for them when choosing and deciding between several geosites that they wish to visit. It is defined as:

$$
I m=\frac{\sum_{k=1}^{K} I v_{k}}{K}
$$

where $I v_{k}$ is the assessment/score of one geotourist for each subindicator and $K$ is the total number of geotourists. Note that the Im parameter can have any value in the range from 0.00 to 1.00 .

After each respondent rated the importance of every subindicator, the average value of each subindicator was calculated and the final value of that subindicator was the Importance factor.

Afterwards, the value of the Importance factor $(I m)$ was multiplied by the value that was given by experts (also from 0.00 to 1.00) who evaluated the current state and value of each subindicator. In this research, the authors of this paper had the role of experts and they were responsible for giving scores for each subindicator in the M-GAM model (for both analyzed geosites).

For the purpose of determining the preferences of Iranian geotourists, a survey to calculate the Importance factor (Im) for all 27 subindicators in the M-GAM model (was administered among Iranian geotourists in January, February, and March 2019. It was carried out both online and by pen and paper. A total of 170 respondents were included in the survey through a snowball sampling approach. The respondents were a mix of people with diverse occupations not related to the field of geosciences. All of the respondents had visited at least two geosites in Iran in the past two years. From Table 2 we can see that the average age of the entire sample was 34.3 years and that the majority of respondents $(49 \%)$ possessed a bachelor degree.

Table 2. Socio-demographic profile of the respondents.

\begin{tabular}{cc}
\hline Gender & \\
Male & $61.7 \%$ \\
Female & $38.3 \%$ \\
\hline Average age & 34.3 \\
\hline Education level & \\
Secondary school & $8.5 \%$ \\
Faculty (Bachelor degree) & $49 \%$ \\
Faculty (Master degree) & $31 \%$ \\
Faculty (Ph.D.) & $11.5 \%$ \\
\hline
\end{tabular}

The questionnaire was divided into two parts. The first part consisted of questions about the socio-demographic profile of respondents (gender, age, education). The second part was dedicated to gathering data about the importance for each subindicator in the MGAM model among Iranian geotourists. Each respondent was asked to rate the importance of each of the 27 subindicators in the M-GAM model and determine how important each one was for them when giving preference to one geosite over another. Each subindicator 
was rated by each respondent using a five-point Likert scale-0.00, 0.25, 0.50, 0.75 and 1.00 - with 0 meaning not important at all and 1 meaning very important, in the same way as it was done by experts.

Afterwards, the Importance factor (Im) for each subindicator was multiplied by the subindicator values given by experts, which provided the new total values (Table 3) that were further added up according to the M-GAM equations.

Table 3. Subindicator values given by experts for each analyzed geosite and the Im values collected through a survey.

\begin{tabular}{|c|c|c|c|c|c|}
\hline \multirow{2}{*}{$\begin{array}{l}\text { Main Indicators/Subindicators } \\
\text { I Scientific/Educational Values (VSE) }\end{array}$} & \multicolumn{2}{|c|}{$\begin{array}{l}\text { Values Given } \\
\text { by Experts }\end{array}$} & \multirow[t]{2}{*}{ Im } & \multicolumn{2}{|c|}{ Total } \\
\hline & $\mathrm{GS}_{1}$ & $\mathrm{GS}_{2}$ & & $\mathrm{GS}_{1}$ & $\mathrm{GS}_{2}$ \\
\hline 1. Rarity $\left(\operatorname{SIMV} V_{1}\right)$ & 0.5 & 0.5 & 0.93 & 0.46 & 0.46 \\
\hline 2. Representativeness $\left(\operatorname{SIMV}_{2}\right)$ & 0.75 & 0.75 & 0.75 & 0.56 & 0.56 \\
\hline 3. Knowledge on geoscientific issues $\left(\operatorname{SIMV}_{3}\right)$ & 0.0 & 0.75 & 0.81 & 0.0 & 0.60 \\
\hline 4. Level of interpretation $\left(\operatorname{SIMV}_{4}\right)$ & 1.0 & 1.0 & 0.84 & 0.84 & 0.84 \\
\hline \multicolumn{6}{|l|}{ II Scenic/Aesthetic Values (VSA) } \\
\hline $\begin{array}{l}\text { 5. Viewpoints (each must present a particular } \\
\text { angle of view and be situated less than } 1 \mathrm{~km} \\
\text { from the site) }\left(S I M V_{5}\right)\end{array}$ & 0.75 & 0.75 & 0.93 & 0.70 & 0.70 \\
\hline $\begin{array}{l}\text { 6. Surface (each considered in quantitative } \\
\text { relation to other) }\left(\operatorname{SIMV}_{6}\right)\end{array}$ & 0.5 & 0.75 & 0.74 & 0.37 & 0.55 \\
\hline 7. Surrounding landscape and nature $\left(\operatorname{SIM} V_{7}\right)$ & 0.5 & 1.0 & 0.91 & 0.45 & 0.91 \\
\hline 8. Environmental fitting of sites $\left(\operatorname{SIM} V_{8}\right)$ & 1.0 & 1.0 & 0.79 & 0.79 & 0.79 \\
\hline \multicolumn{6}{|l|}{ III Protection (VPr) } \\
\hline 9. Current condition $\left(S I M V_{9}\right)$ & 1.0 & 0.75 & 0.90 & 0.90 & 0.67 \\
\hline 10. Protection level $\left(S I M V_{10}\right)$ & 0.5 & 0.5 & 0.71 & 0.35 & 0.35 \\
\hline 11. Vulnerability $\left(\operatorname{SIM} V_{11}\right)$ & 0.75 & 0.5 & 0.74 & 0.55 & 0.37 \\
\hline 12. Suitable number of visitors $\left(\operatorname{SIM} V_{12}\right)$ & 0.75 & 1.0 & 0.70 & 0.52 & 0.70 \\
\hline \multicolumn{6}{|l|}{ I Functional Values (VFn) } \\
\hline 13. Accessibility $\left(S I A V_{1}\right)$ & 0.75 & 0.75 & 0.67 & 0.50 & 0.50 \\
\hline 14. Additional natural values $\left(S I A V_{2}\right)$ & 0.75 & 0.50 & 0.54 & 0.40 & 0.27 \\
\hline 15. Additional anthropogenic values $\left(S I A V_{3}\right)$ & 0.25 & 0.50 & 0.61 & 0.15 & 0.30 \\
\hline 16. Vicinity of emissive centers $\left(S I A V_{4}\right)$ & 0.0 & 0.50 & 0.61 & 0.0 & 0.30 \\
\hline 17. Vicinity of important road network $\left(S I A V_{5}\right)$ & 0.75 & 0.75 & 0.82 & 0.61 & 0.61 \\
\hline 18. Additional functional values $\left(S I A V_{6}\right)$ & 0.50 & 0.50 & 0.73 & 0.36 & 0.36 \\
\hline \multicolumn{6}{|l|}{ II Touristic Values (VTr) } \\
\hline 19. Promotion $\left(\mathrm{SIAV}_{7}\right)$ & 0.0 & 0.5 & 0.63 & 0.0 & 0.31 \\
\hline 20. Annual number of organized visits $\left(S I A V_{8}\right)$ & 0.25 & 0.5 & 0.62 & 0.15 & 0.31 \\
\hline 21. Vicinity of visitors center $\left(S I A V_{9}\right)$ & 0.25 & 0.25 & 0.57 & 0.14 & 0.14 \\
\hline $\begin{array}{l}\text { 22. Interpretative panels (characteristics of text } \\
\text { and graphics, material quality, size, fitting to } \\
\text { surroundings, etc.) }\left(S I A V_{10}\right)\end{array}$ & 0.25 & 0.5 & 0.54 & 0.13 & 0.27 \\
\hline 23. Annual number of visitors $\left(S I A V_{11}\right)$ & 0.25 & 0.75 & 0.65 & 0.17 & 0.49 \\
\hline $\begin{array}{l}\text { 24. Tourism infrastructure (pedestrian } \\
\text { pathways, resting places, garbage cans, toilets, } \\
\text { wellsprings, etc.) (SIAV } 12)\end{array}$ & 0.25 & 0.25 & 0.85 & 0.21 & 0.21 \\
\hline $\begin{array}{l}\text { 25. Tour guide service (expertise level, } \\
\text { knowledge of foreign language(s), } \\
\text { interpretative skills, etc.) }\left(S I A V_{13}\right)\end{array}$ & 0.25 & 0.25 & 0.46 & 0.11 & 0.11 \\
\hline 26. Hostelry service $\left(S I A V_{14}\right)$ & 0.75 & 0.25 & 0.48 & 0.36 & 0.12 \\
\hline 27. Restaurant service $\left(S I A V_{15}\right)$ & 0.5 & 0.25 & 0.47 & 0.23 & 0.11 \\
\hline
\end{tabular}


Finally, the M-GAM equation was defined and is presented in the following form:

$$
\begin{aligned}
& \text { M-GAM }=M V+A V, \\
& M V=\sum_{i=1}^{n} I m_{i} \times M V_{i}, \\
& A V=\sum_{i=1}^{n} I m_{j} \times A V_{j} .
\end{aligned}
$$

As can be seen from the M-GAM equation, the value of the Importance factor (Im), which was rated by geotourists (for each subindicator separately) is multiplied by the value given by experts (also separately for each subindicator). This was done for each subindicator in the model.

The Importance factor can be considered as a universal feature as it has found its role and application not only in geotourism but also in the assessment of cultural heritage in the Cultural Route Evaluation Model (CREM) published by Božić and Tomić [62] and for the assessment of spas in the Spa Assessment Model (SAM) published by Tomić and Košić [63]. Henceforth, its continuous application for different types of tourism in different countries and for different market segments is very appealing for future research as it can be very useful for managing and planning various tourism activities.

\section{Results and Discussion}

For the purpose of this research two canyons in Central Iran were selected and analyzed by applying the M-GAM method for geosite assessment. Additionally, we also calculated and analyzed the $I m$ values for Iranian geotourists and compared them to Serbian and Slovenian geotourists. Tables 4 and 5, as well as Figure 6, show us the final results of the assessment.

Table 4. Overall ranking of the analyzed geosites by M-GAM.

\begin{tabular}{|c|c|c|c|}
\hline Main Indicators/Subindicators & $\underset{\text { (Iman) }}{\operatorname{Im}}$ & $\begin{array}{c}\operatorname{Im} \\
\text { (Serbia) }\end{array}$ & $\underset{\text { (Slovenia) }}{\operatorname{Im}}$ \\
\hline \multicolumn{4}{|l|}{ I Scientific/Educational Values (VSE) } \\
\hline 1. Rarity $\left(\operatorname{SIMV} V_{1}\right)$ & $0.93 *$ & $0.89 *$ & 0.78 \\
\hline 2. Representativeness $\left(S I M V_{2}\right)$ & 0.75 & 0.79 & 0.77 \\
\hline 3. Knowledge on geoscientific issues $\left(\operatorname{SIMV}_{3}\right)$ & 0.81 & 0.45 & 0.77 \\
\hline 4. Level of interpretation $\left(\operatorname{SIMV}_{4}\right)$ & $0.84^{*}$ & $0.85 *$ & $0.94 *$ \\
\hline Average Im Value & 0.83 & 0.75 & 0.82 \\
\hline \multicolumn{4}{|l|}{ II Scenic/Aesthetic Values (VSA) } \\
\hline $\begin{array}{l}\text { 5. Viewpoints (each must present a particular } \\
\text { angle of view and be situated less than } 1 \mathrm{~km} \\
\text { from the site) }\left(S I M V_{5}\right)\end{array}$ & $0.93 *$ & 0.79 & 0.78 \\
\hline $\begin{array}{l}\text { 6. Surface (each considered in quantitative } \\
\text { relation to other) }\left(\operatorname{SIMV}_{6}\right)\end{array}$ & 0.74 & 0.54 & 0.40 \\
\hline 7. Surrounding landscape and nature $\left(\operatorname{SIM} V_{7}\right)$ & $0.91 *$ & $0.95 *$ & 0.65 \\
\hline 8. Environmental fitting of sites $\left(\operatorname{SIM} V_{8}\right)$ & 0.79 & 0.68 & 0.55 \\
\hline Average Im Value & 0.84 & 0.74 & 0.59 \\
\hline
\end{tabular}

\begin{tabular}{cccccc}
\hline \multirow{2}{*}{ Geosite Label } & \multicolumn{2}{c}{ Main Values } & \multicolumn{2}{c}{ Additional Values } & Field \\
\cline { 2 - 5 } & VSE + VSA + VPr & $\sum$ & VFn + VTr & $\sum$ & \\
\hline Shadows Canyon-GS & $1.86+2.31+2.32$ & 6.49 & $2.02+1.50$ & 3.52 & $\mathrm{Z}_{21}$ \\
Canyon of Jinns-GS & $2.46+2.95+2.09$ & 7.50 & $2.34+2.07$ & 4.41 & $\mathrm{Z}_{21}$ \\
\hline
\end{tabular}

Table 5. Comparison of Im values between Iranian, Serbian, and Slovenian geotourists. 
Table 5. Cont

\begin{tabular}{|c|c|c|c|}
\hline Main Indicators/Subindicators & $\begin{array}{c}\text { Im } \\
\text { (Iran) }\end{array}$ & $\begin{array}{c}I m \\
\text { (Serbia) }\end{array}$ & $\begin{array}{c}I m \\
\text { (Slovenia) }\end{array}$ \\
\hline \multicolumn{4}{|l|}{ III Protection (VPr) } \\
\hline 9. Current condition $\left(S I M V_{9}\right)$ & $0.90 *$ & 0.83 & $0.87 *$ \\
\hline 10. Protection level $\left(S I M V_{10}\right)$ & 0.71 & 0.76 & 0.81 \\
\hline 11. Vulnerability $\left(\operatorname{SIM} V_{11}\right)$ & 0.74 & 0.58 & 0.82 \\
\hline 12. Suitable number of visitors $\left(\operatorname{SIM} V_{12}\right)$ & 0.70 & 0.42 & $0.89 *$ \\
\hline Average Im Value & 0.76 & 0.64 & 0.84 \\
\hline \multicolumn{4}{|l|}{ I Functional Values (VFn) } \\
\hline 13. Accessibility $\left(S I A V_{1}\right)$ & 0.67 & 0.75 & 0.64 \\
\hline 14. Additional natural values $\left(S^{\prime} A V_{2}\right)$ & 0.54 & 0.71 & 0.47 \\
\hline 15. Additional anthropogenic values $\left(S I A V_{3}\right)$ & 0.61 & 0.70 & 0.43 \\
\hline 16. Vicinity of emissive centers $\left(S I A V_{4}\right)$ & 0.61 & 0.48 & 0.28 \\
\hline 17. Vicinity of important road network $\left(S I A V_{5}\right)$ & 0.82 & 0.62 & 0.53 \\
\hline 18. Additional functional values $\left(S I A V_{6}\right)$ & 0.73 & 0.59 & 0.35 \\
\hline Average Im Value & 0.66 & 0.64 & 0.45 \\
\hline \multicolumn{4}{|l|}{ II Touristic Values (VTr) } \\
\hline 19. Promotion $\left(S I A V_{7}\right)$ & 0.63 & $0.85 *$ & 0.52 \\
\hline 20. Annual number of organized visits $\left(S I A V_{8}\right)$ & 0.62 & 0.56 & 0.59 \\
\hline 21. Vicinity of visitors center $\left(S I A V_{9}\right)$ & 0.57 & $0.87 *$ & 0.53 \\
\hline $\begin{array}{l}\text { 22. Interpretative panels (characteristics of text } \\
\text { and graphics, material quality, size, fitting to } \\
\text { surroundings, etc.) }\left(S I A V_{10}\right)\end{array}$ & 0.54 & 0.81 & 0.69 \\
\hline 23. Annual number of visitors $\left(S I A V_{11}\right)$ & 0.65 & 0.43 & 0.31 \\
\hline $\begin{array}{l}\text { 24. Tourism infrastructure (pedestrian } \\
\text { pathways, resting places, garbage cans, toilets, } \\
\text { wellsprings, etc.) (SIAV } 12)\end{array}$ & $0.85 *$ & 0.73 & 0.50 \\
\hline $\begin{array}{l}\text { 25. Tour guide service (expertise level, } \\
\text { knowledge of foreign language(s), } \\
\text { interpretative skills, etc.) }\left(S I A V_{13}\right)\end{array}$ & 0.46 & $0.87^{*}$ & 0.70 \\
\hline 26. Hostelry service $\left(S I A V_{14}\right)$ & 0.48 & 0.73 & 0.20 \\
\hline 27. Restaurant service $\left(S I A V_{15}\right)$ & 0.47 & 0.78 & 0.41 \\
\hline Average $I m$ Value & 0.58 & 0.73 & 0.49 \\
\hline
\end{tabular}

* The best ranked subindicators.

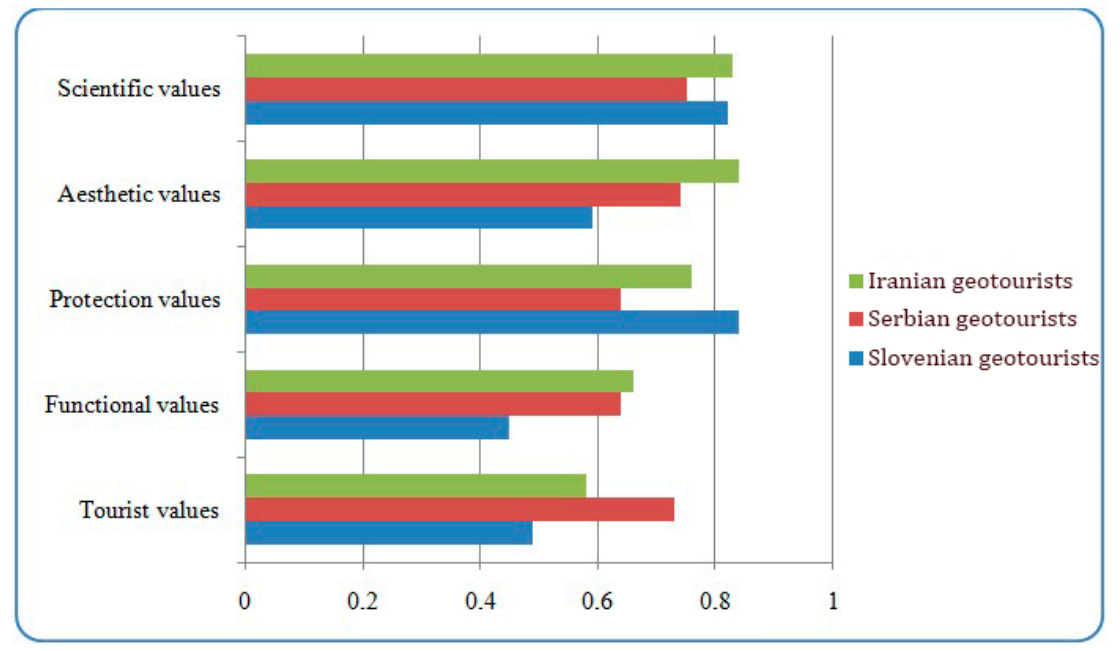

Figure 6. Comparison of average Im values (among five M-GAM subindicator groups) for Iranian, Serbian, and Slovenian geotourists. 
From Table 4, significant differences are noticed between the Main Values of both geosites. Further analysis showed that Shadows Canyon had much lower scientific and aesthetic values than the Canyon of Jinns, while the protection values were higher in the case of Shadows Canyon. Such low scientific values for Shadows Canyon were only because of the subindicator "knowledge on geoscientific issues". This subindicator had minimal value due to the fact that Shadows Canyon is unknown to the wider public as well as among the scientific community. So far there have been no publications about this geosite. However, if we take a look at all other subindicators of scientific values we can see that Shadows Canyon possessed high values. In this case, the anonimity of this geosite among the scientific community was negative for the assessment. However, due to the fact that it is still not known by a lot of people and it is well preserved and pristine, it had higher protection values than the Canyon of Jinns because of its current condition. When it came to aesthetic values, Shadows Canyon had lower values mainly due to the subindicator "surrounding landscape and nature".

Looking at the Additional Values a significant difference between the two geosites can be noticed once again. Both functional and touristic values were higher in the case of the Canyon of Jinns. Due to the remoteness of Shadows Canyon, the subindicator related to the vicinity of emissive centers was rated with minimal value and that is the main reason why Shadows Canyon had lower functional values than the Canyon of Jinns. Looking at touristic values, we notice that in the case of Shadows Canyon almost every subindicator in this group had lower or equal values to those of the Canyon of Jinns. Hostelry and restaurant service were the only two exceptions. The reason for this is the vicinity of the nearby town of Jandaq, which offers food and accommodation services. However, given the fact that these two subindicators were among the least important according to Iranian geotourists, they did not have a big impact on the final results of the assessment. One of the more important subindicators was related to promotional activities. Shadows Canyon is currently not promoted on any level, which is one of the main reasons why it remains unknown to a wider audience. Furthermore, the highest Importance value given by Iranian geotourists was related to tourism infrastructure. This, along with promotional activities, needs to be the primary focus of geosite management in order to attract more tourists to these and other geosites in the future.

In the case of Shadows Canyon, much more effort is needed for improvement in the future. The Main Values were mostly similar to those of the Canyon of Jinns, apart from the subindicator related to knowledge on geoscientific issues. However, this can be corrected relatively quickly by publishing papers and other material about this geosite. Therefore, this geosite possesses all of the necessary natural values for geotourism development, but more effort is needed from the scientific community in the future. When it comes to Additional values, more attention should be paid toward every subindicator in the touristic values group (apart from restaurant and hostelry service) since all of them were rated with minimal values ( 0 and 0.25$)$. However, the primary focus of tourism workers and the local government should be on promotional activities (through websites, brochures, and maps) and tourist infrastructure (interpretive panels and visitor centers) as they were rated as most important among Iranian geotourists.

Furthermore, one of the aims of this research was also to compare the Im values of Iranian geotourists with the values of Serbian and Slovenian geotourists. Based on the Im factor, the best ranked subindicators (marked with * in Table 5) for Iranian geotourists were Rarity and Viewpoints, both with a $0.93 \mathrm{Im}$ score. These were followed by Surrounding landscape and nature (0.91), Current condition (0.90), Tourism infrastructure (0.85) and Level of interpretation (0.84). The least important subindicators were Tour guide service, Hostelry and Restaurant service. If we take a look at the average Im values for each subindicator group, we notice that aesthetic $(0.84)$ and scientific values $(0.83)$ were rated the highest, followed by protection (0.76), functional (0.66) and touristic values (0.58). From this we can conclude that Iranian geotourists preferred geosites of high scientific value 
along with high scenic values. They did not give that much importance to tourist and functional values.

By comparing the Im values to those of Serbian and Slovenian geotourists we can see that the scientific values (VSE) of geosites were most important for Iranian geotourists (0.83), followed closely $(0.82)$ by Slovenian geotourists. When it comes to aesthetic values (VSA) of geosites, Iranian geotourists considered this very important $(0.84)$, much more than Slovenian (0.59) and Serbian (0.74) geotourists. However, when it comes to protection values (VPr), Slovenian geotourists considered this as the most important value, as opposed to Serbian geotourists, who considered this as the least important $(0.64)$ geosite value. Functional (VFn) and touristic values (VTr) were among the least important for Slovenian geotourists as well as Iranian. However, Serbian geotourists considered tourist values as one of the most important, particularly the subindicators related to tour guide service and visitor centers. These types of differences are mainly due to cultural differences among the three analyzed nations. A more detailed comparison of average Im values can be seen in Figure 6.

The biggest difference among Iranian, Serbian, and Slovenian geotourists can be noticed in the case of aesthetic, protection, and tourist values. This can be somewhat explained by different traditions and big cultural differences among these three groups. Slovenian geotourists considered nature protection the most important while aesthetic values were not as important to them as they were for Iranian and Serbian geotourists. This is mostly related to their positive attitude toward nature, especially its protection, and it is deeply rooted in their culture and upbringing. This was not the case in Serbia during the past. However, in recent years this is slowly changing and an increasing trend and awareness for nature protection is emerging among Serbian geotourists and Serbian people in general. This is one issue that the geosite management in Serbia will have to deal in the future. Further research should determine how big these changes are, given the dynamic nature of geosite management in Serbia and its continuous evolution. Serbian geotourists still considered food and beverage along with tour guide service as some of the most important elements at a destination while Slovenian and Iranian geotourists gave very little importance to these elements and considered nature conservation and aesthetic values as the most important. Moreover, additional research is necessary to further determine the deeper reasons behind these differences in the future.

According to the classification of geotourists by Božić and Tomić (2015), there are two groups: "general" and "pure" geotourists. The former includes casual geotourists who visit geosites primarily for the purpose of pleasure and some limited intellectual stimulation, while the latter includes geotourists who purposefully select geosites to visit for the purpose of personal, educational, or intellectual improvement and enjoyment. Considering our results, we can consider Iranian geotourists more as "pure" since they gave less importance to human-induced values (such as hostelry and restaurant service and tour guide service) and gave more importance to the natural values of a geosite. The results can also be analyzed from the perspective of current literature on nature tourism. Several studies $[64,65]$ have pointed out that nature tourists are more interested in ethical issues linked to the wide experience of visitation than in the idea of untouched nature. Would geotourists be different in this regard? The research carried out showed interest in nature as a prominent factor. However, future research needs to focus on other aspects of visitor interest to further explore the link between geotourism and other forms of nature tourism.

\section{Conclusions}

According to the results and the values of the Im factor, Iranian geotourists considered the rarity of a geosite and the number and quality of viewpoints as most important motives for visit. This should be kept in mind when planning future geotourism activities along with the necessity for basic tourism infrastructure and promotional activities, which is considered most important when it comes to tourist values. 
According to the assessment results of Shadows Canyon and the Canyon of Jinns we can conclude that both geosites possess great geotourism potential, mainly based on natural values, especially in the case of Shadows Canyon. Based on the Importance factor values for Iranian geotourists it can be concluded that future activities at these two sites as well as others in Iran should be primarily focused on promotion and infrastructure construction. Basic tourism infrastructure, interpretive panels, and, later, also visitor centers should be constructed in order to attract more tourists to these geosites in the future. At the moment, the Canyon of Jinns has a slight advantage over Shadows Canyon mostly because it is already somewhat known among tourists, while Shadows Canyon still remains to be discovered by a wider audience. Better promotional activities through websites, brochures, and maps are required in order to attract Iranian tourists and a high quality tour guide service is required for foreign tourists. Significant improvement of these factors would bring more domestic and foreign tourists to these geosites, thus benefiting the local population and economy by opening new job opportunities and eventually higher income for the local community.

One of the limitations of this study is that only Iranian geotourists participated in the study. This further limits the generalizability of the findings. More studies, similar to those in Slovenia and Serbia, are necessary in order to gather valuable data about geotourists' preferences throughout the world. Further studies should be focused on geotourists in different countries and for different segments of the tourism market.

Author Contributions: Conceptualization, N.T. and B.S.; methodology, N.T.; formal analysis, N.T. and B.S.; writing-original draft preparation, N.T., S.B.M., Q.H. and B.S.; writing-review and editing, N.T. and H.A.S.L.; investigation, B.S.; visualization, B.S. and H.A.S.L. All authors have read and agreed to the published version of the manuscript.

Funding: This research received no external funding.

Institutional Review Board Statement: Not applicable.

Informed Consent Statement: Not applicable.

Data Availability Statement: No new data were created or analyzed in this study. Data sharing is not applicable to this article.

Conflicts of Interest: The authors declare no conflict of interest.

\section{References}

1. Božić, S.; Tomić, N. Canyons and gorges as potential geotourism destinations in Serbia: Comparative analysis from two perspectives-general geotourists' and pure geotourists'. Open Geosci. 2015, 7, 531-546. [CrossRef]

2. Ranney, W.; Glotfelty, M. Journey to the Grand Canyon: A geologic and hydrologic excursion across Arizona's magnificent heartland. In Geologic Excursions in Southwestern North America; Geological Society America: Boulder, CO, USA, 2019.

3. Pellitero, R.; González-Amuchastegui, M.J.; Ruiz-Flaño, P.; Cañadas, E.S. Geodiversity and Geomorphosite Assessment Applied to a Natural Protected Area: The Ebro and Rudron Gorges Natural Park (Spain). Geoheritage 2010, 3, 163-174. [CrossRef]

4. Cocean, G.; Cocean, P. An Assessment Gorges for Purposes Identifying Geomorphosites Geotourism Value in the Apuseni Mountains (Romania). Geoheritage 2016, 9, 71-81. [CrossRef]

5. Began, M.; Višnić, T.; Djokić, M.; Vasiljevic, D.A. Interpretation Possibilites Geoheritage in Southeastern Serbia-Gorge and Canyon Study. Geoheritage 2016, 9, 237-249. [CrossRef]

6. Telbisz, T.; Stergiou, C.L.; Mindszenty, A.; Chatzipetros, A. Karst features and related social processes in the region the Vikos Gorge and Tymphi Mountain (Northern Pindos National Park, Greece). Acta Carsologica 2019, 48, 29-42. [CrossRef]

7. Khodadadi, M. A new dawn? The Iran nuclear deal and the future the Iranian tourism industry. Tour. Manag. Perspect. 2016, 18, 6-9. [CrossRef]

8. O'Gorman, K.D.; McLellan, L.; Baum, T. Tourism in Iran: Central control and indigeneity. In Tourism and Indigenous Peoples; Elsevier BV: Amsterdam, The Netherlands, 2007; pp. 251-264.

9. Gray, M. Geodiversity: Valuing and Conserving Abiotic Nature; John Wiley \& Sons: Chichester, UK, 2004.

10. Gray, M. Geodiversity: The origin and evolution a paradigm. In the History Geoconservation. Geological Society; Burek, C.V., Prosser, C.D., Eds.; Special Publications: London, UK, 2008; Volume 300, pp. 31-36.

11. Pourahmad, A.; Hosseini, A.; Pourahmad, A.; Zoghi, M.; Sadat, M. Tourist Value Assessment Geotourism and Environmental Capabilities in Qeshm Island, Iran. Geoheritage 2018, 10, 687-706. [CrossRef] 
12. Bahaee, M.; Pisani, M.J.; Shavakh, F. Residents' Attitudes toward International Tourism: A Case Iran. J. Tour. Recreat. 2014, 1, 1-14. [CrossRef]

13. Amrikazemi, A. Introducing Geotourism in Iran. In Proceedings of the 10th International Ecotourism Conference, Cairns, Australia, 21-25 October 2002.

14. Amrikazemi, A. Atlas the Qeshm Geotourism, a Look at the Geological Features the Qeshm Island; Geological Survey Iran: Tehran, Iran, 2004.

15. Tomić, N.; Božić, S. A modified geosite assessment model (MGAM) and its application on the Lazar Canyon area (Serbia). Int. J. Environ. Res. 2014, 8, 1041-1052.

16. Tičar, J.; Tomić, N.; Breg Valjavec, M.; Zorn, M.; Marković, S.B.; Gavrilov, M.B. Speleotourism in Slovenia: Balancing between mass tourism and geoheritage protection. Open Geosci. 2018, 10, 344-357. [CrossRef]

17. Ghazi, J.M.; Ólafsdóttir, R.; Tongkul, F.; Ghazi, J.M. Geological Features for Geotourism in the Western Part Sahand Volcano, NW Iran. Geoheritage 2012, 5, 23-34. [CrossRef]

18. Ghorbani, M. A Summary Geology Iran. In Springer Geology; Springer Science and Business Media LLC: Berlin/Heidelberg, Germany, 2012; pp. 45-64.

19. Fookes, P.; Knill, J. The application engineering geology in the regional development northern and central Iran. Eng. Geol. 1969, 3, 81-120. [CrossRef]

20. Nasab, H.V.; Clark, G.A.; Torkamandi, S. Late Pleistocene dispersal corridors across the Iranian Plateau: A case study from Mirak, a Middle Paleolithic site on the northern edge the Iranian Central desert (Dasht-e Kavir). Quat. Int. 2013, 300, 267-281. [CrossRef]

21. Mohseni, H.; Hamed, M.; Behbahani, R.; Moeeni, M. Geochemistry siliciclastic sediments the Semnan Province and NE Isfahan Province (Iran), implication for provenance. Geopersia 2017, 7, 55-69. [CrossRef]

22. Yahya, S.V.; Zamaniyan, E. Geotourism Potentials Jenni, Sardar and Tafto Canyons (Case Study: Tabas County). In Proceedings of the International Geosciences Congress, Tehran, Iran, 22-24 February 2016.

23. Ruban, D.A. Geotourism-A geographical review the literature. Tour. Manag. Perspect. 2015, 15, 1-15. [CrossRef]

24. Dowling, R.; Newsome, D. Geotourism: Definition, Characteristics and International Perspectives. In Handbook Geotourism; Edward Elgar Publishing: Cheltenham, UK, 2018; Chapter 1; pp. 1-22.

25. Ólafsdóttir, R.; Tverijonaite, E. Geotourism: A Systematic Literature Review. Geoscience 2018, 8, 234. [CrossRef]

26. Wang, L.; Tian, M.; Wen, X.; Zhao, L.; Song, J.; Sun, M.; Wang, H.; Lan, Y.; Sun, M. Geoconservation and geotourism in Arxan-Chaihe Volcano Area, Inner Mongolia, China. Quat. Int. 2014, 349, 384-391. [CrossRef]

27. Štrba, L'. Analysis Criteria Affecting Geo-site Visits by General Public: A Case Slovak (Geo)Tourists. Geoheritage 2019, 11, 291-300. [CrossRef]

28. Pralong, J.P. A method for assessing the tourist potential and use geomorphological sites. Géomorphologie Relief Process. Environ. 2005, 3, 189-196. [CrossRef]

29. Tomić, N. The potential Lazar Canyon (Serbia) as a geotourism destination: Inventory and evaluation. Geogr. Pannonica 2011, 15, 103-112. [CrossRef]

30. Reynard, E.; Fontana, G.; Kozlik, L.; Scapozza, C. A method for assessing "scientific" and "additional values" geomorphosites. Geogr. Helv. 2007, 62, 148-158. [CrossRef]

31. Brilha, J.B. Inventory and Quantitative Assessment Geosites and Geodiversity Sites: A Review. Geoheritage 2016, 8, 119-134. [CrossRef]

32. Fassoulas, C.; Mouriki, D.; Dimitriou, P.D.; Iliopoulos, G. Quantitative Assessment Geotopes as an Effective Tool for Geoheritage Management. Geoheritage 2012, 4, 177-193. [CrossRef]

33. Różycka, M.; Migoń, P. Visitors' background as a factor in geosite evaluation. The case Cenozoic volcanic sites in the Pogórze Kaczawskie region, SW Poland. Geotourism Geoturystyka 2014, 34, 3-18. [CrossRef]

34. Różycka, M.; Migoń, P. Customer-Oriented Evaluation Geoheritage on the Example Volcanic Geosites in the West Sudetes, SW Poland. Geoheritage 2018, 10, 23-37. [CrossRef]

35. Kubalíková, L.; Kirchner, K. Geosite and geomorphosite assessment as a tool for geoconservation and geotourism purposes: A case study from Vizovickávrchovina Highland (eastern part the Czech Republic). Geoheritage 2016, 8, 5-14. [CrossRef]

36. Rybár, P. Assessment attractiveness (value) geotouristic objects. Acta Geoturistica 2010, 1, 13-21.

37. Štrba, L'. Identification and evaluation geosites along existing tourist trail as a primary step geotourism development: Case study from the Spiš region (Slovakia). Geoj. Tour. Geosites 2015, 16, 126-140.

38. Štrba, L'.; Rybár, P.; Baláž, B.; Molokáč, M.; Hvizdák, L.; Kršák, B.; Lukáč, M.; Muchová, L.; Tometzová, D.; Ferenčíková, J. Geosite assessments: Comparison methods and results. Curr. Issues Tour. 2015, 18, 496-510. [CrossRef]

39. Pál, M.; Albert, G. Comparison geotourism assessment models: And experiment in Bakony-Balaton UNSECO Global Geopark, Hungary. Acta Geoturistica 2018, 9, 1-13. [CrossRef]

40. Serrano, E.; González-Trueba, J.J. Assessment geomorphosites in natural protected areas: The Picos de Europa National Park (Spain). Géomorphologie Relief Process. Environ. 2005, 3, 197-208. [CrossRef]

41. Bruschi, V.M.; Cendrero, A. Geosite evaluation. Can we measure intangible values? IL Quat. 2005, 18, $293-306$.

42. Coratza, P.; Giusti, C. Methodological proposal for the assessment the scientific quality geomorphosites. IL Quat. 2005, 18, 307-313.

43. Erhartič, B. Geomorphosite assessment. Acta Geogr. Slov. 2010, 50, 295-319. [CrossRef] 
44. Hose, T.A. Geotourism-Selling the Earth to Europe. In Engineering Geology and the Environment; Marinos, P.G., Koukis, G.C., Tsiambaos, G.C., Stournaras, G.C., Eds.; AA Balkema: Rotterdam, The Netherlands, 1997; pp. 2955-2960.

45. Pereira, P.; Alves, M.I.C. Geomorphosite assessment in Montesinho Natural Park (Portugal). Geogr. Helv. 2007, 62, 159-168. [CrossRef]

46. Reynard, E. Scientific research and tourist promotion geomorphological heritage. Geogr. Fis. Din. Quat. 2008, 31, 225-230.

47. Zouros, N.C. Geomorphosite assessment and management in protected areas Greece Case study the Lesvos island-coastal geomorphosites. Geogr. Helv. 2007, 62, 169-180. [CrossRef]

48. Antić, A.; Tomić, N. Geoheritage and geotourism potential the Homolje area (eastern Serbia). Acta Geoturistica 2017, 8, 67-78. [CrossRef]

49. Boškov, J.; Kotrla, S.; Jovanović, M.; Tomić, N.; Lukić, T.; Rvović, I. Application the preliminary geosite assessment model (GAM): The case the Bela Crkva municipality (Vojvodina, North Serbia). Geogr. Pannonica 2015, 19, 146-152. [CrossRef]

50. Božić, S.; Tomić, N.; Pavić, D. Canyons as potential geotourism attractions Serbia—comparative analysis Lazar and Uvac canyons by using M-GAM model. Acta Geoturistica 2014, 5, 18-30.

51. Bratić, M.; Marjanović, M.; Radivojević, A.R.; Pavlovic, M. M-GAM method in function tourism potential assessment: Case study the Sokobanja basin in eastern Serbia. Open Geosci. 2020, 12, 1468-1485. [CrossRef]

52. Tomić, N.; Marković, S.B.; Korać, M.; Mrđić, N.; Hose, T.A.; Vasiljević, D.A.; Jovičić, M.; Gavrilov, M.B. Exposing mammoths: From loess research discovery to public palaeontological park. Quat. Int. 2015, 372, 142-150. [CrossRef]

53. Tomić, N.; Antić, A.; Marković, S.B.; Đorđević, T.; Zorn, M.; Breg Valjavec, M. Exploring the potential for speleotourism development in eastern Serbia. Geoheritage 2019, 11, 359-369. [CrossRef]

54. Vukoičić, D.; Milosavljević, S.; Valjarević, A.; Nikolić, M.; Srećković-Batoćanin, D. The evaluation geosites in the territory National park 'Kopaonik' (Serbia). Open Geosci. 2018, 10, 618-633. [CrossRef]

55. Antić, A.; Tomić, N.; Marković, S.B. Karst geoheritage and geotourism potential in the Pek River lower basin (eastern Serbia). Geogr. Pannonica 2019, 23, 32-46. [CrossRef]

56. Antić, A.; Tomić, N. Assessing the speleotourism potential together with archaeological and palaeontological heritage in Risovača Cave (Central Serbia). Acta Geoturistica 2019, 10, 1-11.

57. Vuković, S.; Antić, A. Speleological approach for geotourism development in Zlatibor county (west Serbia). Turizam 2019, 23, 53-68. [CrossRef]

58. Tomić, N.; Marković, S.B.; Antić, A.; Tešić, D. Exploring the potential for geotourism development in the Danube Region Serbia. Int. J. Geoheritage Parks 2020, 8, 123-139. [CrossRef]

59. Antić, A.; Tomić, N.; Marković, S.B. Karst-based geotourism in Eastern Carpathian Serbia: Exploration and evaluation natural stone bridges. Geoconservation Res. 2020, 3, 62-80.

60. Antić, A.; Tomić, N.; Đorđević, T.; Radulović, M.; Đević, I. Speleological objects becoming showcaves: Evidence from the Valjevo karst area in Western Serbia. Geoheritage 2020, 12, 1-12. [CrossRef]

61. Jonić, V. Comparative analysis Devil's town and Bryce canyon geosites by applying the modified geosite assessment model (M-GAM). Researches Review the Department Geography. Tour. Hotel Manag. 2018, 47, 113-125.

62. Božić, S.; Tomić, N. Developing the Cultural Route Evaluation Model (CREM) and its application on the Trail Roman Emperors, Serbia. Tour. Manag. Perspect. 2016, 17, 26-35. [CrossRef]

63. Tomić, N.; Košić, K. Developing the Spa Assessment Model (SAM) and its application on the Kopaonik-Jastrebac spa zone (Serbia). Tour. Manag. Perspect. 2020, 36, 100753. [CrossRef]

64. Nowaczek, A.; Smale, B. Exploring the predisposition travellers to qualify as ecotourists: The Ecotourist Predisposition Scale. J. Ecotourism 2010, 9, 45-61. [CrossRef]

65. Ruhanen, L. The prominence eco in ecotourism experiences: An analysis post-purchase online reviews. J. Hosp. Tour. Manag. 2019, 39, 110-116. [CrossRef] 